\title{
Geostatistical support for categorization of metal ore resources in Poland
}

\section{Introduction}

The proper categorization of mineral resources is still a matter commonly discussed in world literature. Despite a great number of proposed methodologies, no standard and universally accepted categorization system has been developed and consented up to now. From the point of view of investors and stoke-exchange collars, the category of mineral resources should reflect the credibility of their estimation and the confidence in the recognition of the continuity of both the geological structure of the deposit and the deposit parameters. Generally, two groups of methods can be distinguished: (i) those based upon mutual relationships between the geometry of exploration grid and the area under categorization, and (ii) those applying various elements of Matheron's geostatistics. The new, comprehensive reviews and descriptions of methodologies can be found in: Mwasinga (2001), Sinclaire and Blackwell (2002), Arik (2002), Souza et al. (2009), and Silva and Boisvert (2014).

The mineral resources categorization system applied in Poland is based upon the two criteria: economic pertinence of given raw material and the degree of deposit recognition represented by categories and corresponding, maximum (permissible) values of relative estimation errors of mean deposit parameters and resources: D (>40\%), $\mathrm{C}_{2}(40 \%), \mathrm{C}_{1}(30 \%)$, B (20\%) and A (10\%) (Nieć et al. 2012).

* Professor, ** Ph.D. Eng., AGH University of Science and Technology, Faculty of Geology, Geophysics and Environmental Protection, Krakow, Poland; e-mail: mucha@geol.agh.edu.pl 
The Australasian JORC Code 2012 system "for Reporting of Exploration Results, Mineral Resources and Ore Reserves", quite popular in the world of mining and economic geology, includes three categories of resources, differing in confidence in their estimation: "inferred" (low level of confidence), "indicated" (reasonable level of confidence) and "measured" (high level of confidence). These three categories can be roughly correlated with the Polish categories of resources estimation: "inferred" $\cong \mathrm{D}+\mathrm{C}_{2}$, "indicated" $\cong \mathrm{C}_{1}$ and "measured" $\cong \mathrm{A}+\mathrm{B}$ (Sobczyk and Saługa 2013).

An important criterion applied in the JORC Code is the proper recognition of the continuity of both the geological structure and the quality of given raw-material (i.e., continuity of deposit parameters). This criterion has been accepted as one of the components of the categorization system of Polish metal ore resources $(\mathrm{Zn}-\mathrm{Pb}$ and $\mathrm{Cu}-\mathrm{Ag}$ ) proposed below and referred in the JORC Code requirements.

The continuity of raw-material deposit parameters can be quantified geostatistically with the semivariogram - as a dissimilarity measure of the values of representative parameters or with the autocorrelation function - as a similarity measure of the values of representative parameters. Both measures lead to the same results as they describe the continuity of deposit parameters but the former method is traditional and commonly applied to the description of the variability of deposit parameters in Matheron's geostatistics. Such a characterization

A
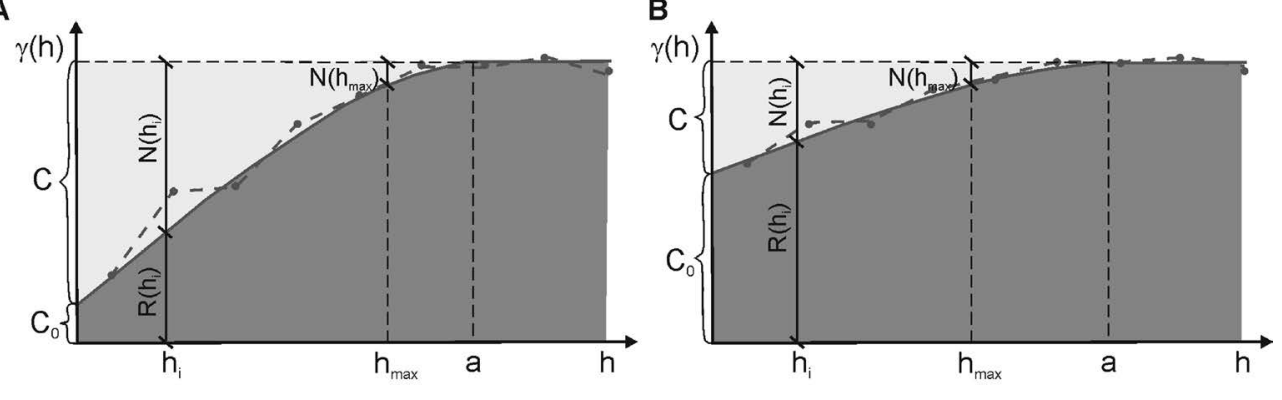

Fig. 1. Example of sample semivariograms and spherical models of parameter variability A) parameter of high continuity and high smoothness of changes,

B) parameter of low continuity and low smoothness of changes

Explanations: axis of ordinates: $\gamma(h)$ - semivariogram, average squared difference of values, axis of abscissae: $h$-distance between measurement sites within deposit, 1 - field of random variability, 2 - field of non-random variability, 3 - sample semivariogram, 4 - spherical model of parameter variability

$C_{0}$ - measure of local variability of parameter (nugget variance), $C$-measure of spatial variability, $a$-range of semivariogram, $N\left(h_{i}\right)$ and $R\left(h_{j}\right)$ - respective, non-random and random components of parameter variability for distance $h_{i}, h_{\max }$ - range to which the non-random component of parameter variability is statistically significant,

$$
\begin{aligned}
r_{A}\left(h_{i}\right)= & \frac{N\left(h_{i}\right)}{R\left(h_{i}\right)+N\left(h_{i}\right)}=\frac{N\left(h_{i}\right)}{C_{0}+C}-\text { coefficient of autocorrelation for distance } h_{i} \\
& \text { (the share of non-random component in the total variability) }
\end{aligned}
$$

Rys. 1. Przykład semiwariogramu i modelu sferycznego

A) parametr o wysokiej ciągłości i płynności zmian, B) parametr o małej ciągłości i płynności zmian 
of the continuity of deposit parameters is applied below to the categorization of Polish metal ore deposits.

For a set of the results of deposit sampling, the semivariogram reflects the dependence between the mean variability of a given deposit parameter (precisely - the mean squared differences of parameter values) and the mean distance between measurement (sampling) sites. The structure of variability is best illustrated by a scatterplot of semivariogram. For deposit parameters estimated with the geostatistical kriging procedure, it is approximated with a single (or a sum of several), principal, continuous analytical function (functions) authorized in the geostatistics. These theoretical semivariograms play the role of geostatistical variability models and they characterize average dissimilarity of parameter values for given distance between the points of deposit. Their patterns close to zero lag distances provide information on the continuity of changes of the parameter values. The low values of theoretical semivariogram for lag distances approximating zero $\left(C_{0}\right)$ reveal the high continuity of a given parameter (i.e., continuous changes of parameter values within an orebody). On the contrary, the high values of semivariogram for lag distances approximating zero demonstrate the low continuity of the parameter (Fig. 1).

\section{Proposed principle of resources categorization}

From the point of view of geologists assessing a mineral deposit, any categorization methodology should be accurate and simple. Bearing these expectations in mind, we applied two quantitative criteria based upon: (i) the values of the autocorrelation coefficient as a measure of continuity and (ii) the permissible (maximum) values of estimation errors.

Considering the first criterion, we propose the following values of autocorrelation coefficients (i.e., the share of non-random component of variability - Fig. 1), which define the ranges (distances) of the resources categories around the measurement sites (e.g., exploration wells):

- "measured" category (A + B in the Polish system) - the values of autocorrelation coefficient from 1 to $2 / 3$,

- "indicated" category $\left(\mathrm{C}_{1}\right.$ in the Polish system $)$ - the values of autocorrelation coefficient from $2 / 3$ to $1 / 3$,

- "inferred" category (partly $\mathrm{C}_{2}$ in the Polish system) - the values of autocorrelation coefficient from $1 / 3$ to $1 / 20$,

- "out-of-doors" category (partly D in the Polish system) - the values of autocorrelation coefficient from $1 / 20$ to 0 .

The principle of resources categorization referred to the continuity of the deposit parameter is illustrated in Fig. 2 for a variability of parameter described with the standardized semivariogram, as defined in Chapter 2. The semivariogram model attains a value of 1 for a distance equal to the range of semivariogram. 
24 Mucha and Wasilewska-Błaszczyk 2015 / Gospodarka Surowcami Mineralnymi - Mineral Resources Management 31(4), 21-34

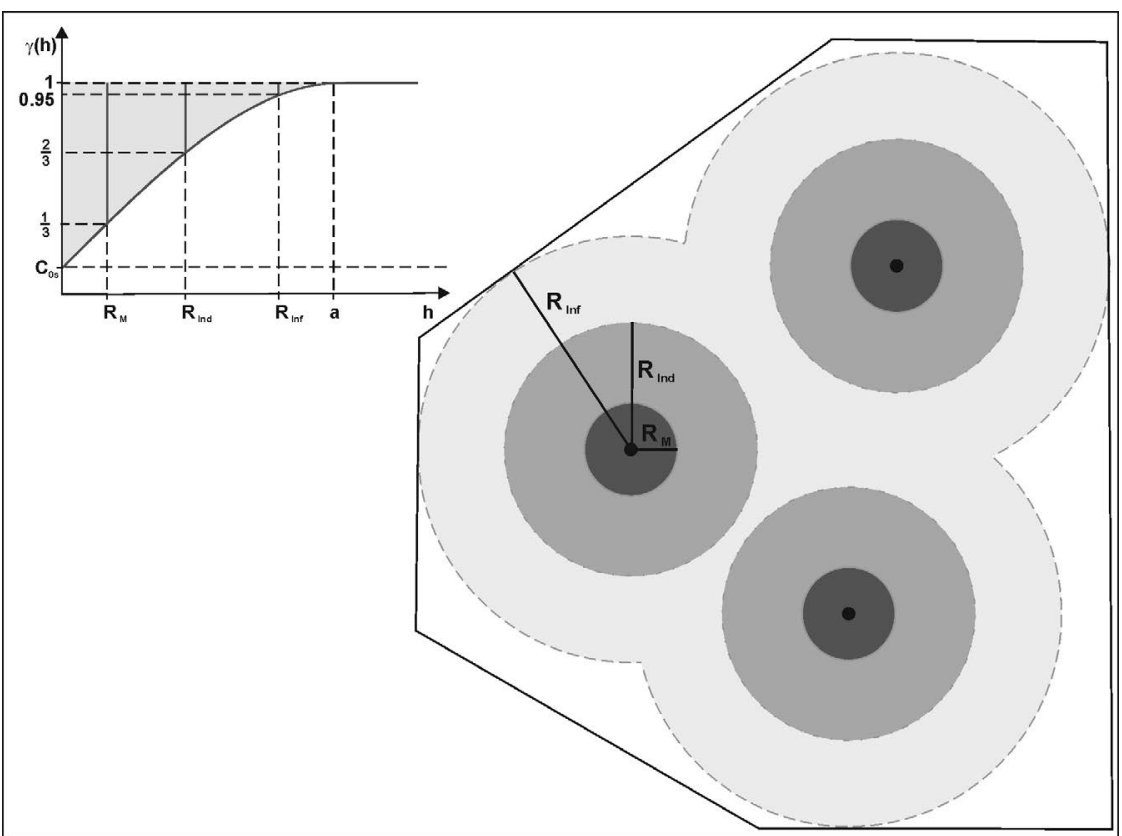

Fig. 2. The illustrated principle of resources categorization based on the continuity of representative deposit parameter under the conditions of the spherical model of the standardized semivariogram Explanations: $\mathrm{R}_{\mathrm{M}}, \mathrm{R}_{\text {Ind }}, \mathrm{R}_{\mathrm{Inf}}$ - radii of maximum ranges of categories: "measured" $(\mathrm{M})$, "indicated" (Ind), "inferred" (Inf), respectively

Rys. 2. Ilustracja zasady kategoryzacji zasobów złoża opartej na ciągłości reprezentatywnego parametru złożowego w warunkach izotropowego modelu sferycznego semiwariogramu standaryzowanego

The second criterion of resources categorization is based upon the relative, standard errors of resources estimations calculated for the parts of deposit defined with the first criterion. We propose the following permissible values of errors determined as the errors of ordinary kriging:

- "measured" category (A + B in the Polish system) $-10 \%$ error,

- "indicated" category $\left(\mathrm{C}_{1}\right.$ in the Polish system $)-20 \%$ error,

- "inferred" category (partly $\mathrm{C}_{2}$ in the Polish system) - 30\% error,

- "out-of-doors" category (partly D in the Polish system) - 50\% error.

The final categories of deposit resources should be decided by ascribing the areas defined by the continuity criterion of a representative deposit parameter to categories defined by the calculated errors of resources estimations.

\section{Study materials}

The geostatistical analysis of the continuity of selected deposit parameters for categorization purposes was carried out by using the results of sampling of underground workings 
at two $\mathrm{Zn}-\mathrm{Pb}$ ore mines (Trzebionka and Klucze) and two $\mathrm{Cu}-\mathrm{Ag}$ ore mines (Konrad and Polkowice-Sieroszowice). Only the Klucze Mine (Olkusz Zn-Pb ore district, Upper Silesia) and the Polkowice-Sieroszowice Mine (Lubin Copper District, Fore-sudetic Monocline) are currently in operation. Mining operations at the Trzebionka Mine (Chrzanów Zn-Pb district, Upper Silesia) and at the Konrad Copper Mine (North-sudetic Depression, Grodziec Syncline) have ceased. We used also the additional dataset for the Polkowice-Sieroszowice Mine, i.e., the results of core sampling of numerous exploration wells. Unfortunately, such data from the remaining mines could not be included in our calculations due to a geostatistically insufficient number of wells and a rather limited credibility of the determined deposit parameters (ore grade, orebody thickness and bulk density) resulting from generally low core recovery and the lack of detailed descriptions of procedures applied in core sampling and in sample preparation for chemical analyses.

From the point of view of categorization effectiveness, the continuity should be analyzed for the most representative deposit parameter, which is the abundance of usable component (here - the abundance of metal). Unfortunately, we could not use this parameter in studies on $\mathrm{Zn}-\mathrm{Pb}$ ore deposits due to specific sampling procedure of mine workings which precluded the determination of the thickness of economic-grade ore and, thus, eliminated the calculation of metals abundances. Consequently, we limited our continuity analysis only to the combined metals content $[\mathrm{Zn}+\mathrm{Pb}]$ in a mine face. For $\mathrm{Cu}-\mathrm{Ag}$ ore, the vertical channel sampling system enables geologists to precisely contour the economic-grade ore and, thus, the abundances of metals can be calculated at any sampling site.

The dataset is sufficiently large to ensure the representativeness of analyses (Table 1). The preliminary geostatistical data analysis revealed the lack of significant anisotropy in the

Table 1. The maximum ranges of resources categories determined from the models of standardized semivariograms of parameters from $\mathrm{Cu}-\mathrm{Ag}$ and $\mathrm{Zn}-\mathrm{Pb}$ ore deposits

Tabela 1. Zasięgi maksymalne kategorii zasobów określone na podstawie modeli semiwariogramów standaryzowanych badanych parametrów złóż $\mathrm{Cu}-\mathrm{Ag}$ i Zn-Pb

\begin{tabular}{|l|c|c|c|c|c|}
\hline \multicolumn{1}{|c|}{ Ore deposit } & \multicolumn{3}{c|}{ Cu-Ag } & \multicolumn{2}{c|}{$\mathrm{Zn}-\mathrm{Pb}$} \\
\hline Mine & \multicolumn{2}{c|}{ Polkowice-Sieroszowice* } & Konrad** & Klucze*** & Trzebionka*** \\
\hline Parameter & \multicolumn{2}{|c|}{$\mathrm{qCu}\left[\mathrm{kg} / \mathrm{m}^{2}\right]$} & $\mathrm{qCu}\left[\mathrm{kg} / \mathrm{m}^{2}\right]$ & $\mathrm{Zn}+\mathrm{Pb}[\%]$ & $\mathrm{Zn}+\mathrm{Pb}[\%]$ \\
\hline Amount of data & 95 & 79,854 & 278 & 448 & 458 \\
\hline Data source & $\mathrm{Bh}$ & $\mathrm{MW}$ & $\mathrm{MW}$ & $\mathrm{MW}$ & $\mathrm{MW}$ \\
\hline $\mathrm{R}_{\max }-$ Measured $(\mathrm{A}+\mathrm{B})$ & - & - & - & - & - \\
\hline $\mathrm{R}_{\max }-$ Indicated $\left(\mathrm{C}_{1}\right)$ & $500 \mathrm{~m}$ & $200 \mathrm{~m}$ & - & - & $30 \mathrm{~m}$ \\
\hline $\mathrm{R}_{\max }-$ Inferrred $\left(\mathrm{C}_{2}\right)$ & $3,500 \mathrm{~m}$ & $1,150 \mathrm{~m}$ & $76 \mathrm{~m}$ & $60 \mathrm{~m}$ & $80 \mathrm{~m}$ \\
\hline
\end{tabular}

* Lubin Copper District Fore-sudetic Monocline (SW Poland).

** North-sudetic Trough, Grodziec Syncline.

*** Silesian-Cracow $\mathrm{Zn}-\mathrm{Pb}$ ore district (S Poland).

$\mathrm{Bh}$ - boreholes, $\mathrm{MW}$ - mine workings, $\mathrm{qCu}$ - copper abundance, $\mathrm{R}_{\max }$ - radii (maximum) of ranges of resources categories. 
variability of the analyzed deposit parameters. Hence, we recognized that the omnidirectional semivariograms can satisfactorily describe the variability structure of the analyzed parameters. In order to facilitate the interpretation of the results and to ensure the comparability of variability structure patterns of various deposit parameters, we calculated the standardized semivariograms in which the values of "classic" semivariograms are divided by the calculated standard deviations of parameters. The values of sample omnidirectional standardized semivariograms for consecutive lags of distances between the sampling sites (h) are given by the formula:

$$
\gamma_{S}(h)=\frac{\frac{1}{N_{h}} \sum_{i=1}^{N_{h}}\left(z_{i+h}-z_{i}\right)^{2}}{s_{-h} S_{+h}}
$$

$\Leftrightarrow z_{i+h}, z_{i} \quad$ - values of a deposit parameter at sampling sites distant by (approximately) " $h$ ",

$N_{h} \quad-$ number of pairs of sampling sites distant by (approximately) " $h$ ",

$s_{-h}, s_{+h} \quad-$ standard deviations of tail and head values.

The application of standardized semivariogams enabled us to quickly determine the values of autocorrelation coefficients for a given distance by subtracting from 1 the values of the theoretical semivariogram.

\section{Results}

All standardized sample semivariograms of studied deposit parameters from $\mathrm{Cu}-\mathrm{Ag}$ and $\mathrm{Zn}-\mathrm{Pb}$ deposits presented in Fig. 3 can be approximated with the so-called "spherical model" described by the equation:

$$
\begin{array}{ll}
\gamma_{s}(h)=C_{0 s}+C_{s}\left[1.5 \frac{h}{a}-0.5 \frac{h^{3}}{h^{3}}\right] & \text { for } h \leq a \\
\gamma_{s}(h)=C_{0 s}+C_{s} & \text { for } h \geq a
\end{array}
$$

or, in the simplified version:

$$
\gamma_{s}(h)=C_{0 s}+C_{s} \operatorname{sph}\left(\frac{h}{a}\right)
$$

$\Leftrightarrow C_{0 s}-$ standardized nugget effect (i.e., a relative measure of local variability and continuity of a given deposit parameter), 
$C_{s} \quad-$ standardized variance of spatial variability,

a $\quad$ - range of model (theoretical semivariogram).

As an exception, the semivariogram of $\mathrm{Cu}$ abundance in a part of the Polkowice-Sieroszowice deposit calculated for data obtained from the sampling of mine workings was approximated with the model composed of the sum of two basic spherical models (Fig. 3).

In the case of standardized semivariogams, the maximum ranges of particular resource categories can be easily determined graphically from the plots of their models. These ranges
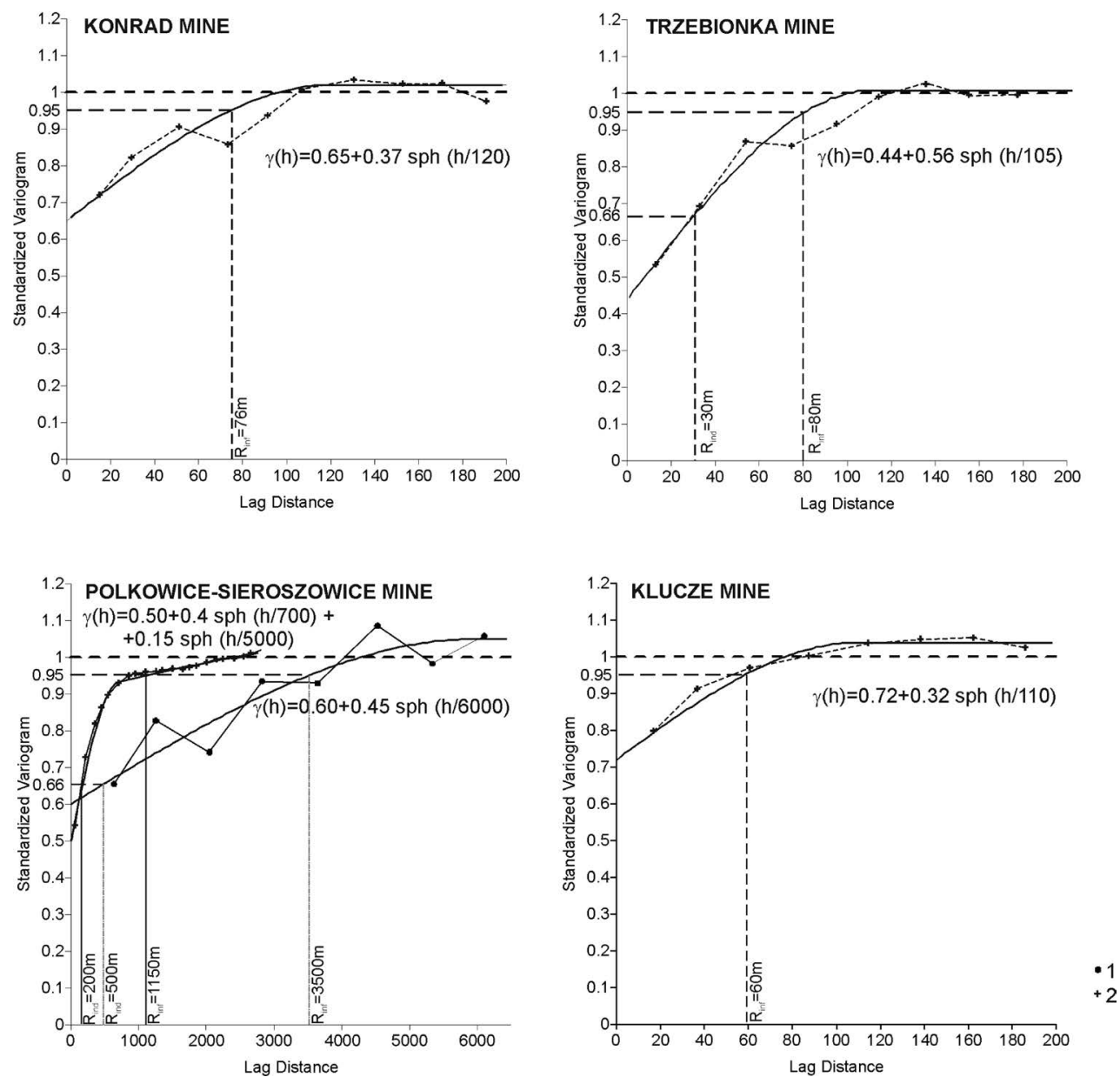

Fig. 3. Standardized omnidirectional semivariograms and geostatistical models of datasets from $\mathrm{Cu}-\mathrm{Ag}$ (Konrad, Polkowice-Sieroszowice) and Zn-Pb (Trzebionka, Klucze) ore deposits 1 - exploration wells, 2 - mine workings,

$\mathrm{R}_{\text {Ind }}, \mathrm{R}_{\mathrm{Inf}}$ - respectively: ranges (maximum) of the Indicated and Inferred categories

Rys. 3. Semiwariogramy standaryzowane i modele geostatystyczne dla danych z fragmentów złóż $\mathrm{Cu}$ (Konrad i Polkowice-Sieroszowice) i Zn-Pb (Trzebionka i Klucze) 
are given by distances for which the values of models (theoretical semivariograms) are: $1 / 3$ for "measured" $(\mathrm{A}+\mathrm{B})$ category, $2 / 3$ for "indicated $\left(\mathrm{C}_{1}\right)$ category and 0.95 for "inferred" $\left(\mathrm{C}_{2}\right)$ category, which are additions of the values of autocorrelation coefficients to 1 .

The value 0.95 taken for the "inferred" category originates from the fact that for long distances (i.e., close to the range of the model) autocorrelation is usually statistically insignificant. In fact, the range of this category should be the maximum distance for which the autocorrelation coefficient is statistically significant. In the presented examples of deposits, the statistical significance of autocorrelations has not been tested and, thus, the value 0.95 has been arbitrarily accepted as a conventional range of statistically significant autocorrelation.

The structure of variability described with the models of the standardized semivariograms (Fig. 3) is typical of parameters known from the ore deposits. It shows a high share of local variability (i.e., high share of nugget variance) indicating a low continuity and low smoothness of changes in the values of the deposit parameters. The variance of local variability $\left(C_{0 s}\right)$ constitutes about $2 / 3$ of the overall variability of a given parameter. The exception is combined metals $[\mathrm{Zn}+\mathrm{Pb}]$ content in a part of the Trzebionka deposit composed of the sphalerite pseudolayers of the earthy structure. Here, the maximum autocorrelation coefficient reaches 0.56 (the nugget variance is equal to 0.44 ), which indicates a higher continuity of this parameter in a relatively large and uniform orebody. At such a high local variability of the deposit parameters, the resources in this part of the deposit cannot be categorized as "measured" $(\mathrm{A}+\mathrm{B})$. Moreover, their inclusion into the "indicated" $\left(\mathrm{C}_{1}\right)$ category is rather limited if the continuity of the deposit parameter is taken as the only categorization criterion (Table 1).

We must emphasize a distinct difference which appears in semivariograms models calculated for data from mine workings and from drillings in a part of the Polkowice-Sieroszowice $\mathrm{Cu}-\mathrm{Ag}$ deposit (Fig. 3, Table 1). The ranges of categories calculated from these two datasets differ by 2-3 times, which generates significant discrepancies in the resources of particular categories. This example demonstrates that the results of semivariograms modeling based upon data from exploration drillings must be treated with very limited confidence.

The discrepancy in resources estimated with the datasets from mine workings and from drillings is illustrated quantitatively for a large (about $6.75 \mathrm{~km}^{2}$ ) fragment of the Polkowice -Sieroszowice $\mathrm{Cu}-\mathrm{Ag}$ deposit explored with 10 wells, in which economic-grade mineralization was found (Fig. 4, Table 2). The ranges of "indicated" and "inferred" resource categories were determined separately for mine-working and for drilling datasets. Then, the mean $\mathrm{Cu}$ abundances and $\mathrm{Cu}$ resources were estimated with the polygon kriging method, and the relative kriging errors were calculated using the ISATIS software. If the contours of estimations are defined, the relative estimation errors of both the mean abundance and the resources are identical. The results summarized in Table 2 clearly demonstrate a nearly threefold difference between $\mathrm{Cu}$ resources estimated from semivariograms models for mine workings and for drillings. More optimistic although less realistic results were obtained for semivariogram models calculated from drilling dataset due to larger resources acquired for the "indicated" category. Estimations of mean $\mathrm{Cu}$ abundances are very similar and the estimation errors 
A

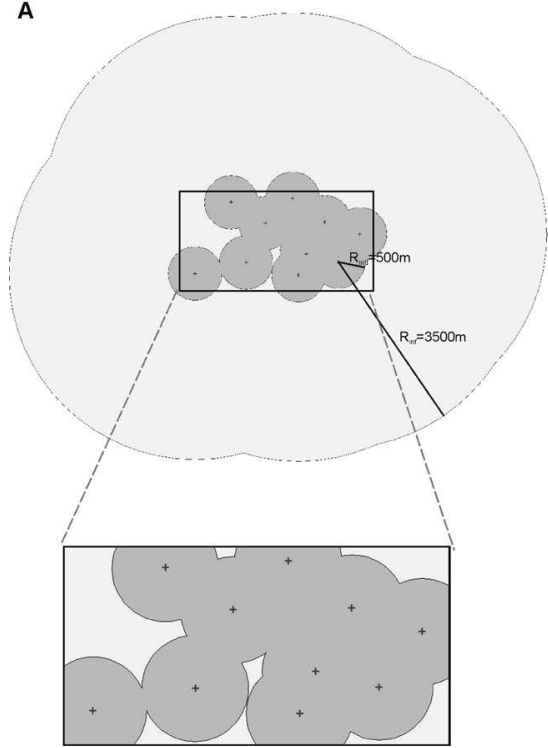

B

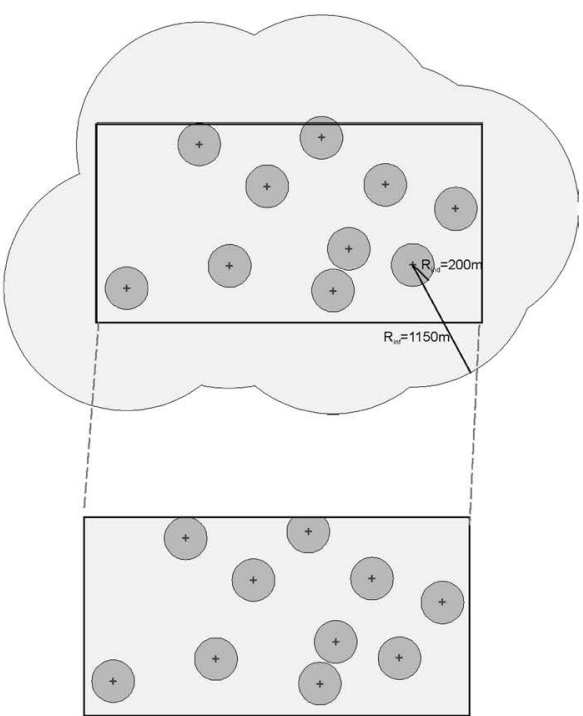

Fig. 4. The ranges of "indicated"(dark-grey) and "inferred" (light-grey) resources categories around exploration wells determined from geostatistical models based upon datasets from exploration wells $B h$ (A) and mine workings $M W$ (B) (fragment of the Polkowice-Sieroszowice $\mathrm{Cu}-\mathrm{Ag}$ deposit)

Rys. 4. Zasięgi kategorii zasobów „indicated” (ciemnoszary) i „inferred” (jasnoszary) wokół otworów wyznaczone na podstawie modeli geostatystycznych dla danych z otworów $B h$ (A)

i wyrobisk górniczych $M W(\mathrm{~B})$ (fragment złoża Polkowice-Sieroszowice)

Table 2. $\mathrm{Cu}$ abundances, $\mathrm{Cu}$ resources and estimation errors estimated with ordinary polygon kriging, for selected area of the Polkowice-Sieroszowice $\mathrm{Cu}-\mathrm{Ag}$ deposit comprising various resources categories shown in Fig. 4

Tabela 2. Wyniki szacowania zasobów Cu i błędów metodą krigingu zwyczajnego poligonowego dla obszarów obejmujących różne kategorie rozpoznania złoża (Fig. 4)

na podstawie modeli geostatystycznych semiwariogramów relatywnych dla danych z otworów wiertniczych i wyrobisk górniczych

\begin{tabular}{|c|c|c|c|c|c|}
\hline \multirow{2}{*}{$\begin{array}{c}\text { Semiwariogram } \\
\text { dataset }\end{array}$} & \multirow{2}{*}{$\begin{array}{l}\text { Radius of } \\
\text { resources } \\
\text { category } \\
{[\mathrm{m}]}\end{array}$} & \multirow{2}{*}{$\begin{array}{c}\text { Area of } \\
\text { resources } \\
\text { category } \\
{\left[\mathrm{km}^{2}\right]}\end{array}$} & \multicolumn{3}{|c|}{$\begin{array}{l}\text { Results of polygon kriging } \\
\text { for relative geostatistical model }\end{array}$} \\
\hline & & & $\begin{array}{c}\mathrm{qCu} \\
{\left[\mathrm{kg} / \mathrm{m}^{2}\right]}\end{array}$ & $\begin{array}{l}\sigma_{\mathrm{KR}} \\
{[\%]}\end{array}$ & $\begin{array}{c}\mathrm{Q} \\
{\left[10^{3} \mathrm{Mg}\right]}\end{array}$ \\
\hline \multirow{2}{*}{$\mathrm{Bh}$} & $\mathrm{R}_{\text {ind }}=500$ & 5.362 & 99.8 & 16.5 & 536 \\
\hline & $\mathrm{R}_{\mathrm{inf}}=3,500$ & 1.386 & 106.3 & 19.7 & 147 \\
\hline \multirow{2}{*}{ MW } & $\mathrm{R}_{\text {ind }}=200$ & 1.245 & 98.4 & 13.0 & 123 \\
\hline & $\mathrm{R}_{\mathrm{inf}}=1,150$ & 5.503 & 101.1 & 14.9 & 556 \\
\hline
\end{tabular}

$\mathrm{Bh}$ - exploration wells (boreholes), $\mathrm{MW}$ - mine workings, $\mathrm{qCu}-\mathrm{Cu}$ abundance in economic-grade deposit, $\sigma_{\mathrm{KR}}-$ relative kriging standard error, $\mathrm{Q}-\mathrm{Cu}$ resources. 
of $\mathrm{Cu}$ resources for the "inferred" category are only slightly (2-3\%) higher than those for the "indicated" category. If we consider the accuracy of the estimations expressed by the kriging errors, the resources of this portion of $\mathrm{Cu}-\mathrm{Ag}$ deposit can be finally categorized as "indicated" $\left(\mathrm{C}_{1}\right)$.

\section{Summary and conclusions}

The characteristic feature of deposit parameters of Polish metal ore deposits is high local variability. In most cases, it results in the poorly marked continuity and smoothness of their values within the orebodies. If the continuity of deposit parameters is accepted as the only criterion of resources categorization the highest, "measured" (A + B) category will occur extremely rarely in the assessments of ore deposits.

The geostatistical variability models of deposit parameters based upon datasets from preliminary exploration drillings may drastically differ from the models based upon datasets obtained from the more accurate exploration in mine workings. Such discrepancies result from strongly contrasting grids spacings of exploration drillings and sampling sites in the mine workings as well as from somewhat different geometries of samples, and from different scales of sampling errors. Nevertheless, a diversity of models gives rise to essential differences in resources estimated for particular categories. Thus, we conclude that a sufficiently credible categorization of resources is only possible when a significant part of the deposit is explored with mine workings, in which the grid of sampling sites is much denser than that of exploration wells.

The results of categorization depend on the size of the assessed deposit area. One must expect the lowering of resources category at the fixed localization of sampling (measurement) sites and with the decreasing area of assessment.

The application of some elements of the JORC Code, particularly the proven continuity of deposit parameters, into the categorization of the resources of Polish metal ore deposits requires further analyses and the search for optimum solutions. In our opinion, the decisive categorization criterion should be the permissible error of resources estimation. The continuity of deposit parameters expressed by the range of autocorrelation coefficient values should play a supplementary role.

The research project was financed from the AGH University of Science and Technology, grant No. 11.11.140.320 


\section{REFERENCES}

Arik, A. 2002 - Comparison of Resource Classification Methodologies With a New Approach. $30^{\text {th }}$ APCOM Symposium Proceedings, Phoenix, Arizona, pp. 57-64.

Mwasinga, P.P. 2001 - Approaching resource classification: General practices and the integration of geostatistics. Computer Applications in the Minerals Industries, Xie, Wang\&Jiang eds, Swets\&Zeintlinger, Lisse, pp. 97-104.

Nieć, M. 2009. Polska i Międzynarodowa Ramowa Klasyfikacja Zasobów (UNCF) złóż kopalin stałych i węglowodorów podobieństwa i różnice. Górnictwo Odkrywkowe R. L, No. 2-3, pp. 50-57 (in Polish).

Nieć et al. 2012 - Nieć, M. (red.), Mucha, J., Sobczyk, E.J. and Wasilewska-Błaszczyk, M. 2012. Metodyka dokumentowania złóż kopalin stałych. Cz. IV - Szacowanie zasobów. Ministerstwo Środowiska, NFOŚiGW, Kraków, 241 pp.

Silva, D.S.F. and Boisvert, J.B. 2014. Mineral resource classification: a comparison of new and existing techniques. The Journal of the Southern African Institute of Mining and Metallurgy Vol. 114, pp. 265-273.

Sinclaire, A.J. and Blackwell, G.H. 2002 - Applied Mineral Inventory Estimation. Cambridge University Press, $381 \mathrm{pp}$.

Sobczyk, E.J. and Saługa, P.W. 2013 - Coal resource base in Poland from the perspective of using the JORC CODE Proceedings of the 23rd World Mining Congress, 235, Montreal, Canada, pp. 1-12.

Souza et al. 2009 - de Souza, L.E., Costa, J.F.C.L. and Koppe, J.C. 2009. A Geostatistical Contribution to Assess the Risk Embedded in Resource Classification Methods. Iron Ore Conference Perth, WA, 27-29 July 2009, pp. $1-10$.

The JORC Code (2012 edition) - Australasian Code for Reporting of Exploration Results, Mineral Resources and Ore Reserves prepared by The Australasian Institute of Mining and Metallurgy (AusIMM), Australian Institute of Geoscientists and Minerals Council of Australia.

\section{GEOSTATYSTYCZNE WSPOMAGANIE KATEGORYZACJI ZASOBÓW POLSKICH ZLÓŻ RUD METALI}

Słowa kluczowe

kategoryzacja, zasoby, rudy metali, semiwariogram, JORC Code

\section{Streszczenie}

W artykule podjęto próbę włączenia pewnych elementów australijskiego systemu raportowania zasobów JORC Code do kategoryzacji polskich złóż Cu-Ag i Zn-Pb. Zaproponowano geostatystyczną metodę kategoryzacji uwzględniającą dwa kryteria: ciągłość parametrów zasobowych opisywaną za pomocą semiwariogramów oraz dopuszczalny relatywny, standardowy błąd oszacowania zasobów określany przy zastosowaniu procedury krigingu zwyczajnego. Według pierwszego kryterium uznano, że do poniżej wymienionych kategorii mogą być zakwalifikowane zasoby wokół punktów rozpoznania (np. otworów wiertniczych) w zasięgach odległości spełniających następujące warunki: kategoria measured (A + B wg polskiej klasyfikacji) - współczynnik autokorelacji przyjmuje wartości z przedziału: od 1 do $2 / 3$, kategoria indicated $\left(C_{1}\right.$ wg polskiej klasyfikacji) - współczynnik autokorelacji przyjmuje wartości z przedziału: od $2 / 3$ do $1 / 3$, kategoria inferred (częściowo $\mathrm{C}_{2}$ wg polskiej klasyfikacji) - współczynnik autokorelacji przyjmuje wartości z przedziału: od 1/3 do 1/20, zasoby poza wymienionymi kategoriami (częściowo D wg polskiej klasyfikacji) - współczynnik autokorelacji przyjmuje wartości z przedziału od $1 / 20$ do 0 . Jako drugie kryterium warunkujące zaliczenie 
partii zasobów do danej kategorii przyjęto wielkość relatywnych, standardowych błędów oszacowań zasobów w obszarach złoża przyporządkowanym kategoriom według pierwszego kryterium. Dla poszczególnych kategorii rozpoznania zaproponowano następujące dopuszczalne wielkości błędów wyznaczanych jako błędy krigingu zwyczajnego: kategoria measured (A + B wg polskiej klasyfikacji) $-10 \%$, kategoria indicated $\left(\mathrm{C}_{1}\right.$ wg polskiej klasyfikacji) $-20 \%$, kategoria inferred $\left(\mathrm{C}_{2} \mathrm{wg}\right.$ polskiej klasyfikacji) - 30\%, zasoby poza wymienionymi kategoriami (D wg polskiej klasyfikacji) - 50\%.

Stwierdzono małą ciągłość parametrów zasobowych polskich złóż rud metali wyrażoną dużym udziałem wariancji zmienności lokalnej (tzw. wariancji samorodków) w całkowitej zmienności tych parametrów. Zwrócono uwagę na niespójność semiwariogramów parametrów zasobowych uzyskanych w oparciu o wyniki opróbowań rdzeni wiertniczych i wyrobisk górniczych skutkującą drastycznym zróżnicowaniem zasięgów kategorii zasobów wokół punktów rozpoznania i w konsekwencji wielkości oszacowanych zasobów. Upoważnia to do konkluzji, że dostatecznie wiarygodna kategoryzacja zasobów jest możliwa tylko na etapie objęcia przynajmniej fragmentu złoża dokładniejszym górniczym rozpoznaniem, z rozstawami punktów opróbowania wielokrotnie mniejszymi niż rozstawy otworów. Stwierdzono, że podstawowym kryterium kategoryzacji zasobów powinien być dopuszczalny błąd oszacowania zasobów a kryterium ciągłości parametrów zasobowych powinno pełnić rolę pomocniczą.

\title{
GEOSTATISTICAL SUPPORT FOR CATEGORIZATION OF METAL ORE RESOURCES IN POLAND
}

\author{
Keywords
}

categorization, resources, metal ore, semivariogram, JORC Code

Abstract

The authors attempted to introduce some components of the Australasian JORC Code system to the categorization of Polish $\mathrm{Cu}-\mathrm{Ag}$ and $\mathrm{Zn}-\mathrm{Pb}$ ore resources. The proposed geostatistical method of resource categorization applies two criteria: continuity of deposit parameters described by semivariograms and permissible, relative standard error of resources estimation determined with the ordinary kriging procedure. Considering the first criterion, we propose the following values of autocorrelation coefficients, which define the ranges (distances) of the resources categories around the measurement sites (e.g., exploration wells): "measured" category (A + B in the Polish system) - the values of the autocorrelation coefficient from 1 to $2 / 3$, "indicated" category $\left(\mathrm{C}_{1}\right.$ in the Polish system) - the values of the autocorrelation coefficient from $2 / 3$ to $1 / 3$, "inferred" category (partly $\mathrm{C}_{2}$ in the Polish system) the values of the autocorrelation coefficient from $1 / 3$ to $1 / 20$, "out-of-doors" category (partly D in the Polish system) - the values of autocorrelation coefficient from $1 / 20$ to 0 .

The second criterion of resources categorization is based upon the relative, standard errors of resources estimations calculated for the parts of deposit defined with the first criterion. The following permissible values of errors determined as the errors of ordinary kriging have been proposed: "measured" category (A + B in the Polish system) - 10\% error, "indicated" category $\left(\mathrm{C}_{1}\right.$ in the Polish system) $-20 \%$ error, "inferred" category (partly $\mathrm{C}_{2}$ in the Polish system) $-30 \%$ error, "out-of-doors" category (partly D in the Polish system) $-50 \%$ error. 
It was found that the Polish metal ore deposits reveal low continuity of deposit parameters, as indicated by a high share of nugget variance in the overall variability of these parameters. Moreover, an inconsistency was observed between the semivariograms of deposit parameters based upon samplings of drill cores and underground mine workings, which results in extreme differences in the ranges of resources categories around the sampling sites. This, in turn, causes radical discrepancies in estimated resources. Thus, it was concluded that the sufficiently credible categorization of resources is only possible when a significant part of the deposit is explored with mine workings, in which the grid of sampling sites is much denser than that of exploration wells. It was proposed that the principal criterion of resources categorization should be the permissible error of estimations whereas the continuity of deposit parameters should only be a supplementary criterion. 
